\title{
MATRICES AND THEIR APPLICATIONS
}




\section{INTRODUCTORY MONOGRAPHS IN MATHEMATICS}

General Editor

A. J. Moakes, M.A.

Numerical Mathematics

A. J. Moakes

Exercises in computing with a desk calculating machine

Mathematics for Circuits

The Core of Mathematics

An introduction to 'modern' mathematics
W. Chellingsworth

A. J. Moakes

A. P. Bowran

O. B. Chedzoy and

Sandra E. Ford 


\title{
MATRIGES AND \\ THEIR APPLIGATIONS
}

\author{
J. R. BRANFIELD and A. W. BELL \\ NOTTINGHAM COLLEGE OF EDUCATION
}

Macmillan Education 
ISBN 978-1-349-81600-2 ISBN 978-1-349-81598-2 (eBook)

DOI 10.1007/978-1-349-81598-2

(C) J. R. Branfield and A. W. Bell 1970

Reprint of the original edition 1970

All rights reserved. No part of this publication may be reproduced or transmitted, in any form or by any means, without permission

First published 1970

Published by

MACMILLAN AND CO LTD

London and Basingstoke

Associated companies in New York, Toronto,

Dublin, Melbourne, Fohannesburg $\mathcal{E}^{\circ}$ Madras 


\section{CONTENTS}

$\begin{array}{rr}\text { Preface } & \text { vii }\end{array}$

Chapter 1. Matrices and their Algebra 1

2. Transformations of the Plane 10

3. Further Transformation Techniques 27

4. Linear Equations 35

5. The Eigenvector 44

6. Application of the Eigenvector to Linear Mappings $\quad 55$

7. Networks and Communications 68

8. Successive Events, Stochastic Processes and Markov Chains

9. Quadratic Forms 113

$\begin{array}{ll}\text { Bibliography } & 130\end{array}$

Answers to Exercises 131 


\section{PREFACE}

THE power and adaptability of the matrix as a mathematical tool is evident by matrix techniques becoming used in an increasing number of fields. No mathematical education is now complete without some knowledge of their use.

The material in this book has come from a course in matrices and their applications given to students training as mathematics teachers. In each section, the starting point is an application or situation in which matrices arise. Techniques are then developed for dealing with the situation, and exercises and investigations are provided through which the reader may extend his understanding of the ideas.

We hope that students in sixth forms, Colleges of Education and of Technology, and in the first year at University will find this material useful. Teachers will find material suitable for extending their own knowledge of the subject, and also some situations which could form the basis of lessons for secondary school children.

We are indebted to our own students on whom we have tried out this material; to Dr. T. J. Fletcher (H.M.I.) for many of the ideas on which Chapters 7 and 8 are based; to the editor of the Monograph series, Mr. A. J. Moakes, for his generous help and encouragement and to the publishers.

Nottingham College of

Education, 1969.
J. R. BRANFIELD

A. W. BELL 